\title{
The Implementation of Whiteboard Animation Video Based on Local Wisdom in Work and Energy Concept to Improve Senior High Schools Students' Learning Interest
}

\author{
Husnatul Hamidiyah ${ }^{1, *}$ Warsono $^{2,}$ Azalia Isma Anggraini ${ }^{1,}$ Surya Jatmika ${ }^{1}$ \\ ${ }^{1}$ Master of Physics Education, Faculty of Mathematics and Natural Sciences, Universitas Negeri Yogyakarta, \\ Indonesia \\ ${ }^{2}$ Department of Physics Education, Faculty of Mathematics and Natural Sciences, Universitas Negeri \\ Yogyakarta, Indonesia \\ *Corresponding author. Email: husnatulhamidiyah.2019@student.uny.ac.id
}

\begin{abstract}
This research aimed to determine the improvement of students learning interest after the learning implementation by using whiteboard animation video based on local wisdom. The research uses a pre-experimental design of group pretest-posttest. The subjects in this resarch were students of grade X MIPA 2 of MAN 2 Yogyakarta. The data in this research were collected using a questionnaire consisting of 20 items to measure students learning interest. The data were analyzed using $\mathrm{N}$-gain to find the improvement of students learning interest. The results shows that the improvement of students learning interest obtain 0.4 in the medium category. So, it can be said that the use the use whiteboard animation video based on local wisdom is effective to improve student interest in learning.
\end{abstract}

Keywords: Whiteboard animation video, Local wisdom, Students learning interest

\section{INTRODUCTION}

Education is conscious and planned effort to create a learning environment of a learning process held by formal institutions in the schools [1]. The most supportive aspects in the delivery of learning are aspects of learning methods and learning device [2]. Physics is a science that studies natural phenomena which occur around us. Physical knowledge consists of many concepts and principles which are generally very abstract. Physics is part of science which takes an important role in life and technology [3].

There are several factors that affect students understanding of physics concepts namely internal factors and external factors. Internal factors include: interest, attention, and learning rhythm, while external factors include: number of students, environment, teacher's control, and activities [4]. The process of delivering concept from teachers to students needs a medium with a purpose of making it easier for students to understand the concept. Media is a tool that is really needed by teachers in creating a good learning process. A good learning process is one of the determinants of the success of the teaching and learning process [5].

Interest is liking, indulgence or pleasure in something [6]. Recent research has revealed that students' interest to science begins to decrease from their early ages. This lack of interest shows the small number of students who qualify the scientific career requirements and ready to engage in social issues. Therefore, there should be a solution to increase student learning interest in school. The solution can be done by applying science in students' daily life [7]. Natural phenomena can increase students learning interest to learn physics [8]. The use of local wisdom is another way to make learning more meaningful and to increase students' willingness to learn [9]. The use of local wisdom will attract students' attention because students have real 
experiences in everyday life that are in accordance with the application of physics [10].

Covid-19 pandemic that has hit various countries has prompted WHO to give an appeal to stop activities of crowd to gather. One of them is learning that is learning activity that carried out face-to-face in class as preventive way to stop the spread of Covid19. Therefore, online learning is an alternative to overcome these problems [11]. The technology of information and communication is the turning point where an approach to teaching theoretical content and the process of scientific reasoning begins. The use of this technology will visualize the real processes of learning activity such the motion of objects to develop students understanding of learning [12].

Students' ability to think creatively and actively are important factors in teaching and learning process [13]. The use of technology in learning activities is believed to improve students' learning abilities [14]. The use of smartphone as learning media is certainly interesting and practical, because it can be accessed anywhere and anytime [15]. Learning multimedia in the form of educational practices can make the learning process more interesting, flexible, increase student concentration and help student understanding, thus having a positive impact on student learning outcomes [16]. Therefore, the whiteboard animation video which is introduced as an educational learning environment needs to be further developed. In this way students can learn more easily because the presentation of the material is more effective and can attract more student attention [16]. Whiteboard animations have a positive effect on attention, engagement and enjoyment [17]. Whiteboard animation videos are the using of videos that describe the process of drawing a finished image on a whiteboard or something that resembles a whiteboard. Unlike traditional animation, whiteboard animation video can dynamically represent concepts (and misconceptions) without focusing on narrative action. The content that is represented dynamically is more prominent and serves as a cue to improve learning animation content. So, it will direct students' interest to learn and get the important and urgency aspects of learning concept [17].

\section{RESEARCH METHOD}

\subsection{Type of the Research}

This study aimed to improve students' interest in learning physics after using whiteboard animation videos for their learning process based on local wisdom in work and energy concepts. This research model is pre-experimental on one group pretestposttest design as shown in Table 1.

Table 1. One-group pretest-posttest design

\begin{tabular}{|l|l|l|}
\hline $\mathrm{O}_{1}$ & $\mathrm{X}$ & $\mathrm{O}_{2}$ \\
\hline Pretest & $\begin{array}{l}\text { Implementation of } \\
\text { whiteboard animation video } \\
\text { based local wisdom }\end{array}$ & Posttest \\
\hline
\end{tabular}

\subsection{Research Setting}

This research was conducted on the second semester of 2020/2021 academic year starting from April to May 2020 in MAN 2 Yogyakarta.

\subsection{Research Subject}

The subject of this study is tenth graders students of Madrasah Aliyah Negeri (MAN) 2 Yogyakarta by using purposive sampling with 24 students in grade $\mathrm{X}$ MIPA 2.

\subsection{Research Variable}

This research used a whiteboard animation video for learning which based on local wisdom as the independent variable. Meanwhile the dependent variable of this study is the students' interest in learning physics.

\subsection{Instruments and Data Collections Techniques}

The research instruments used in this study had been validated by expert judgment. It showed that the learning tools, instructional medias and research instruments are valid and appropriate for this research. Below are examples of whiteboard animation video based on local wisdom in Figure 1 and 2 .

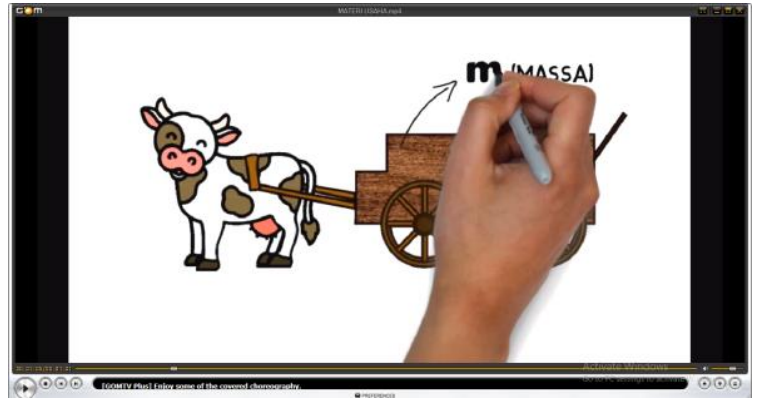

Figure 1 Whiteboard video animation based local wisdom. 


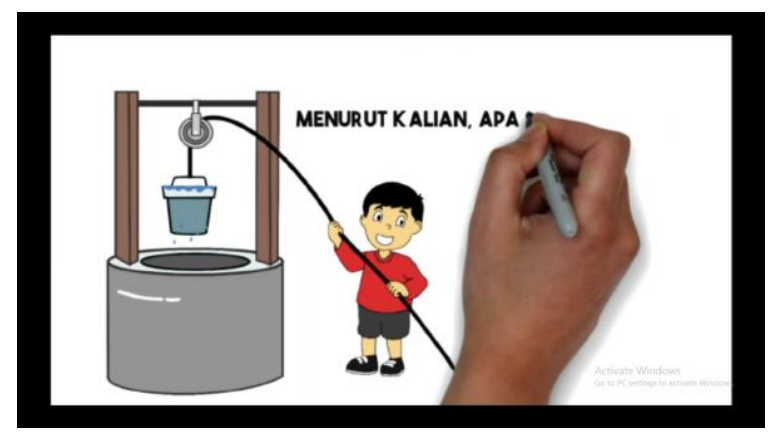

Figure 2 Whiteboard video animation based local wisdom.

This research was started with giving a pretest to students which was continued by doing the learning process using the whiteboard animation videos based on local wisdom in work and energy concepts. The learning model was implemented by using online learning. It was carried out by using Google Classroom application that can be accessed on students' personal computers or smartphones. At the end of the study, posttest was given to the students. The research data were collected by using a questionnaire consists of 20 items in order to measure students' interest in learning. Learning interest questionnaires to measure students learning interest can be accessed in Google Form. Indicators of students' learning interest can be seen in Table 2.

Table 2. Indicator of students' learning interest

\begin{tabular}{|l|l|}
\hline No & Indicator \\
\hline 1 & Happy feeling \\
\hline 2 & Attention \\
\hline 3 & Interest \\
\hline 4 & Student involvement \\
\hline
\end{tabular}

\subsection{Data Analysis}

The results of the questionnaire was obtained from students' pretest and posttest which were analyzed by using $\mathrm{N}$-gain analysis. The tests were carried out using a questionnaire consisted of 20 items with five answer choice adopted from Likert Scale. The N-gain formula shows in Equation 1 and its interpretation in Table 3

$g=\frac{\text { scor posttest }- \text { scor pretest }}{\text { scor } \max -\text { scor pretest }}$

Table 3. The Criteria of Gain Values

\begin{tabular}{|l|l|}
\hline $\mathrm{N}$-Gain & Criteria \\
\hline $\mathrm{g} \geq 0.7$ & High \\
\hline
\end{tabular}

\begin{tabular}{|l|l|}
\hline $0.3 \leq \mathrm{g}<0.7$ & Medium \\
\hline $\mathrm{g}<0.3$ & Low \\
\hline
\end{tabular}

\section{RESULT AND DISCUSSION}

\subsection{Result}

The data on the enhancement in students' learning interest were obtained through the results of the questionnaire before and after learning process by using a whiteboard animation video based on local wisdom. The data were analyzed by using $\mathrm{N}$-gain to get the result of students learning interest. The results are presented in Table 4.

Table 4. The N-gain result of enhancement learning interest.

\begin{tabular}{|l|l|l|}
\hline Classification & $\begin{array}{l}\text { The Number } \\
\text { of Students }\end{array}$ & $\begin{array}{l}\text { Percentage } \\
(\%)\end{array}$ \\
\hline High & 0 & 0 \\
\hline Medium & 15 & 65.2 \\
\hline Low & 8 & 34.8 \\
\hline
\end{tabular}

The increased percentage of students learning interest based on the standard gain were categorized as; $0 \%$ for the high category, $65.2 \%$ as the moderate category, and $34.8 \%$ as the low category which were interpreted to students N-gain graph in Figure 3.

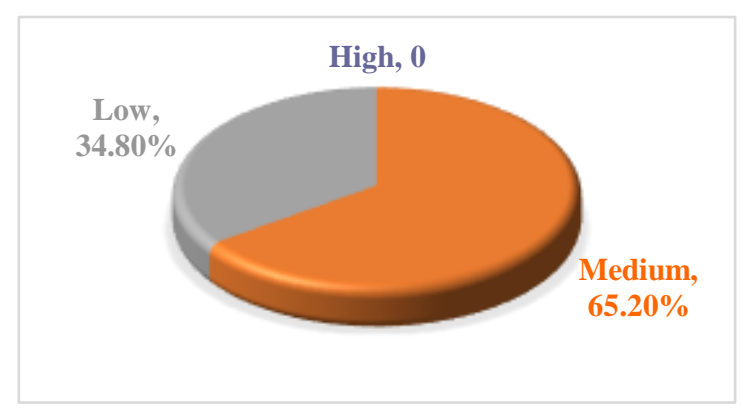

Figure 3 Pie chart of N-gain percentage of learning interests.

Table 5 presents the recapitulation of the $\mathrm{N}$-gain analysis for the average score of students' learning interest based on the results of student pretest and posttest. Based on Table 5, the result shows an average pretest value of 61.82 and an average posttest value of 69.26 in order to obtain the standard gain of 0.4 relatively. The increase in students reasoning abilities were presented in Figure 4. 


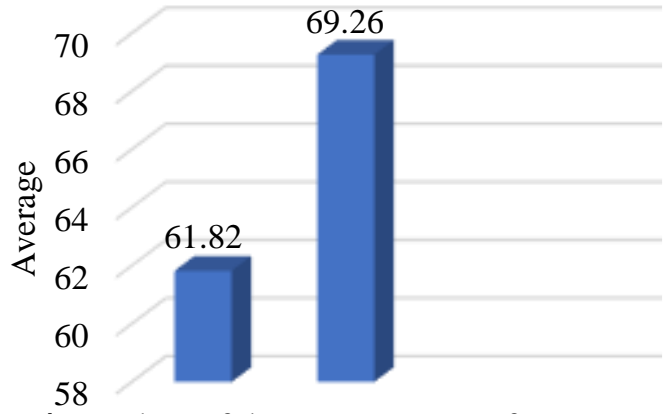

Figure 4 Bar chart of the average score of pre-test and post-test ratings.

Table 5. Recapitulation data of students' learning interest by $\mathrm{N}$-gain analysis

\begin{tabular}{|c|c|c|}
\hline \multicolumn{3}{|l|}{ Average } \\
\hline Pre-test & Post-test & N-gain \\
\hline 61.82 & 69.26 & 0.4 \\
\hline \multicolumn{2}{|l|}{ Category } & Medium \\
\hline
\end{tabular}

\subsection{Discussion}

The increase of Covid-19 cases in Indonesia affects the implementation of face-to-face learning in class directly. Online learning comes up as a solution so that students still can do the learning activities at home. However, it was feared as reason which can cause students bored and decrease their learning interest of physics. Thus, learning physics in work and energy concept was done by using whiteboard animation videos based on local wisdom to increase students learning interest.

The results of data analysis on the increasing in student learning interest was collected based on the criteria for the $\mathrm{N}$-gain value and it shows an increasing in the moderate category [18]. Whiteboard animation videos based on local wisdom are able to present learning which supported by images, graphics, sound and animation content that can attract the students' attention, interests and feelings in learning work and energy concept. This idea is supported by the research of Ibrahim.

Another innovation is; The whiteboard animation may have paid attention to the lessons because this format is fairly new. It is enjoyable to experience innovation [19] attracts attention [20] and arouses curiosity. Whiteboard animation videos based on local wisdom which relates to daily life will make it easier for students to understand problems, so they will interest in solving these problems.
The using of whiteboard animation video based on local wisdom has increased the students learning interest relatively. Moreover, the increase of students in low interest category in learning physics exist because not all of the students have good enough internet connection to support the online learning process. In addition, there are many students complaining about their difficulty in downloading the whiteboard animation video, so they gave up before the lesson began. For the students who still have low category for learning interest, they should be given more motivation so that they will have high interest in learning physics.

\section{CONCLUSION}

Based on the result, it can be concluded that the increase in students learning interest in work and energy concept by using whiteboard animation video based on local wisdom show the medium category. Further research need to notice the availability of students' internet connection.

\section{REFERENCES}

[1] S. Tri, Y.A Agung, Pengembangan Media Videoscribe Berbasis E-Learning pada Mata Pelajaran Komunikasi Data dan Interface di SMK Sunan Drajat Lamongan, Jurnal Pendidikan Teknik Elektro 5(3) (2016) 10681072.

[2] Wahyudin, Sutikno, A. Isa, Keefektifan Pembelajaran Berbantuan Multimedia Menggunakan Metode Inkuiri Terbimbing Untuk Meningkatkan Minat dan Pemahaman Siswa, Jurnal Pendidikan Fisika Indonesia 6(1) (2010) 58-62. DOI: https://doi.org/10.15294/jpfi.v6i1.1105

[3] M. Mustari, Pengaruh Penggunaan Media Gambar Lewat Komputer Terhadap Hasil Belajar Fisika pada Siswa Kelas X SMA Negeri 3 Makassar, Jurnal Ilmiah Pendidikan Fisika Al-Biruni 4(2) (2010) 269-280. DOI: https://doi.org/10.24042/jpifalbiruni.v4i2.98

[4] A. Abbas, M. Yusuf, Faktor-Faktor Kesulitan Belajar Fisika pada Peserta Didik Kelas IPA Sekolah Menengah Atas, Jurnal Pendidikan Fisika 6(1) (2018) 45-49. DOI: https://doi.org/10.24252/jpf.v6i1a8

[5] R. Wijayanti, B. Hasan, R.K. Loganathan, Media Comic Math Berbasis Whiteboard Annimation 
dalam Pelajaran Matematika, Jurnal Riset Pendidikan Matematika 5(1) (2018) 53-63. DOI: http://dx.doi.org/10.21831/jrpm.v5i1.19207

[6] T.J. Wulandari, S. Siagian, A.M. Sibuea, Pengembangan Media Pembelajaran dengan Aplikasi Macromedia Flash pada Mata Pelajaran Matematika, Jurnal Teknologi Informasi dan Komunikasi dalam Pendidikan 5(2) (2019)195209. DOI: https://10.24114/jtikp.v5i2.12598

[7] J.A. Jocz, J. Zhai, A.L. Tan, Inquiry Learning in The Singaporean Context: Factors Affecting Student Interest in School Science, International journal of Science Education 36(15) (2014) 2596-2618.

DOI: http://dx.doi.org/10.1080/09500693.2014.90832 -

[8] C. Waltner, H. Wiesner, A. Rachel, Physics in Context-A Means to Encourage Student Interest in Physics, Physics Education 42(5) (2007) 502-507. DOI: https://doi.org/10.1088/0031-9120/45/5/010

[9] P.Z. Kun, Pembelajaran Sains Berbasis Kearifan Lokal, in: Seminar Nasional Fisika dan Pendidikan Fisika, vol. 2, Universitas Sebelas Maret, Surakarta, 2013, pp. 246-256.

[10] I.N. Dewi, M. Ibrahim, S. Poedjiastoeti, B.K. Prahani, Effectiveness of Local Wisdom Integretef (LWI) Learning Model to Improve Scientific Communication Skills of Junior High School Students in Science Learning, International Journal of Education 1157 (2017) 107-118. DOI: https://doi.org/10.1088/1742$\underline{6596 / 1157 / 2 / 022014}$

[11] A. Sadikin, A. Hamidah, Pembelajaran Daring di Tengah Wabah COVID-19, Jurnal Ilmiah Pendidikan Biologi 6(2) (2020) 214-224. DOI: https://doi.org/10.22437/bio.v6i2.9759

[12] S. Hennessy, R. Deaney, K. Ruthven, Situated Expertisein Integrating Use of Multimedia Simulation into Secondary Science Teaching, International Journalof Science Education 28(7) (2006) 701-732. DOI: http://dx.doi.org/10.1080/09500690500404656

[13] O. Kurniaman, T. Yuliani, M. Mansur, Investigating Think Talk Write (TTW) Learning Model to Enhance Primary Students' Writing Skill, Journal of Teaching and Learning in elementary Education 1(1) (2018) 52-59. DOI: http://dx.doi.org/10.33578/jtlee.v1i1.5394
[14] N. Humairah, Z. Muchtar, M. Sitorus, The development of android-based interactive multimedia for high school students, in: advances in social science education and humanities research, Proceedings of the 5th Annual International Seminar on Transformative Education and Educational Leadership (AISTEEL 2020), vol. 488, Atlantis Press, Amsterdam, 2020, pp. 113-119. DOI: https://doi.org/10.2991/assehr.k.201124.027

[15] J. M. Blair, Animated Autoethnographies: Stop Motion Animation as A Tool for Self-Inquiry and Personal Evaluation, Journal Art Education 67(2) (2014) 6-13. DOI: http://dx.doi.org/10.1080/00043125.2014.11519 $\underline{259}$

[16] P. Barbarić, Marjana, D. Karuović, E. Eleventhe The Interactive Whiteboard and Educational Software as An Addition to The Teaching Process, Tehnicki Vjesnik 25(1) (2018) 255262. DOI: https://doi.org/10.17559/TV20160310117355

[17] S. Turkay, The Effects of Whiteboard Animations on Retention Andsubjective Experiences When Learning Advanced Physicstopics, Journal Computers and Education $98 \quad$ (2016) 102-114. DOI: http://dx.doi.org/10.1016/j.compedu.2016.03.00 $\underline{4}$

[18] R. R. Hake, Analyzing Change/Gain Scores, AREA-D American Education Research Association's Devision D, Measurement and Reaserch Methodology, 1999.

[19] I. Biederman, E. Vessel, Perceptual pleasure and the brain, American Scientist 94(3) (2006) 247253. DOI: https://doi.org/10.1511/2006.3.247

[20] S. Pace, A grounded theory of theflow experiences of web users, International Journal of Human-Computer Studies 60(3) (2003) 327363.

DOI: 